\title{
The perceived extent of ICT integration in intra-university communication among the Kenyan Universities
}

\author{
Rhoda Karimi Gitonga ${ }^{1, *}$, Mwangi Ndirangu ${ }^{2}$, Jason M. Githeko ${ }^{3}$ \\ ${ }^{1}$ School of Business and Public Management, Department of Information Technology, KCA University, Nairobi \\ ${ }^{2}$ Department of curriculum, Instruction \& Educational Management, Egerton University, P.O. Box 536, Egerton \\ ${ }^{3}$ Computer Science Department, Egerton University, P.O. Box 536, Egerton
}

\author{
Email adddress: \\ rhodakarimi@gmail.com (R. K. Gitonga),mndirangu@egerton.ac.ke (M. Ndirangu), githeko@egerton.ac.ke (J. M. Githeko)
}

\section{To cite this article:}

Rhoda Karimi Gitonga, Mwangi Ndirangu, Jason M. Githeko. The Perceived Extent of ICT Integration in Intra-University Communication Among the Kenyan Universities, Communications. Vol. 1, No. 2, 2013, pp. 16-21. doi: 10.11648/j.com.20130102.11

\begin{abstract}
The government and most Kenyan universities have invested heavily in ICT. Universities are buying computers, increasing bandwidth and connectivity, while at the same time enhancing their other infrastructure to harness the potential benefits of this technology. ICT is known to bring about a number of efficiencies in the teaching and learning process, communication and other aspects of university management. However, little is known regarding how this investment is benefiting the country and specifically the university community in Kenya. The purpose of this paper is to report findings of a study carried out to determine the perceived extent of ICT integration in Intra-university Communication in Kenyan universities. The study investigated the availability and use of selected ICT facilities which included mobile phone, bulk SMS system and email broadcast. The research design used was the descriptive survey. The target population comprised of all the students and lecturers in the public and private universities in the Nairobi metropolitan totaling to 80,707 students and 4,377 lecturers. Purposive sampling was used to select three public and three private universities. Stratified random sampling was used to select 386 students and 344 lecturers. Data was analyzed using descriptive statistics. The findings indicated that the majority of students and staff were aware of the ICT resources available for communication within their institutions. Additionally they used these resources. Considering the high rate of adoption of mobile phones in Kenya, this is not surprising. However, in view of the central role that ICT is expected to play in the economic and social progress of many developing nations more work is needed to establish the extent to which ICT supports educational objectives.
\end{abstract}

Keywords: ICT, ICT integration, Intra-university Communication

\section{Introduction}

Worldwide, ICT has been known to support intra- university communication. Studies have been done on ICT resource availability and use. Under ICT resource availability in intra-university communication, [1] observed that college students familiarity and confidence with information technology had created expectations of immediacy, interactivity, personalization and mobility. This is also echoed by [2] in a study titled "It's research made easier! SMS and chat reference perceptions", who reported that more students owned a mobile phone than a lap top or a personal computer. This observation would seem to apply to Kenya as well.

Studies done by [3], [4] and [5] show that attributes such as affordability, portability, convenience, versatility and simplicity in usage makes ICT devices such as mobile phone relevant to the needs of majority of the people and especially age group of 18-24 year olds. This age group is similar to the age of students in the Kenyan universities. In a study to explore the reaction of university students towards the use of SMS in political campaigns, [6] found out that students and the young generation in general were difficult to reach with traditional communication tools. Politicians were using mobile technologies such as bulk SMS system to coordinate events and mobilize the students for political campaigns. [7] argues that university administrators use bulk SMS to coordinate events where the students are away from the university. Bulk SMS enable university administrators to communicate important announcements and notices to all or particular students on issues affecting them.

The government through East African Marine System,(TEAMS), Kenya Education Network, (KENET), Kenya Transparency Communication Infrastructure Project (KTCIP) and universities have invested heavily in ICT and the Kenya national development strategies, Vision2030 and 
Kenya ICT Master Plan place a key role on ICT in the country's economic and social development. However, there is little information on how ICT is being used in Kenyan institutions. Hence it is essential to undertake regular studies to establish the status of ICT and provide information to policy makers and institutional managers as well as staff regarding the use off ICT in our universities in order to ensure that the investment is worthwhile.

This paper will report findings on the availability and use of selected ICT in intra-university communication in $\mathrm{Ke}$ nyan universities.

\subsection{Objective of the Study}

The following was the research objective:

To determine the extent of integration of ICT in intra-university communication in Kenyan Universities.

\subsubsection{Research Question}

The following research question guided this study:

What is the extent of integration of ICT in intra-university communication in Kenyan Universities?

\subsection{Location of the Study}

The study was carried out among students and lecturers in the Nairobi metropolitan. This region had the highest number of both public and private universities.

\subsection{Methodology}

Purposive sampling was used to select the universities from which the sample was drawn. The main objective in this type of sampling was to pick cases that were typical of the population being studied. The researcher's judgment was used to select the respondents who best met the purposes of the study. The three public universities were selected because they were the only public universities with their main campuses within Nairobi metropolitan. The three private universities were selected because they were among the most established among all the private universities. Stratified random sampling was then used to select the two categories of respondents namely students and lecturers. The sample size was calculated using the formulae from [8] where the minimum sample size can be evaluated as follows:

$$
n=\frac{Z^{2} p q}{d^{2}}
$$

Where:

$n=$ the minimum sample size if the target population is greater than 10,000

$Z=$ the standard normal deviate at the required confidence level.

$p=$ the proportion in the target population estimated to have characteristics being measured. Use 0.5 if unknown.

$q=1-p$

$d=$ the margin of error.
If the target population is less than 10,000 then the minimum sample size is obtained using the formula:

$$
n_{s}=\frac{n}{1+\frac{n}{N}}
$$

Where:

$n_{s}=$ the minimum sample if the target sample size is less than 10,000

$n=$ the minimum sample size if the target population is greater than 10,000

$N=$ the estimate of the population size.

Once the required sample size was determined, proportion allocation was used to obtain the number of students and lecturers that were included in the sample from each of the selected universities. Simple random sampling was then used to distribute the questionnaire equally to all the sample recipients. The sample size was calculated using the formulas above with $Z=1.96, \mathrm{p}=\mathrm{q}=0.5$ and $\mathrm{d}=0.05$ to obtain a sample of 386 students and 344 lecturers. However, 231 students' questionnaires and 219 lecturer's questionnaire were collected for analysis. According to [9], it is generally recommended that minimal sample size should be 100 for each major subgroup and 20 - 50 for minor sub group in a survey research. Therefore the sample size used was appropriate for analysis.

\section{Results and Discussion}

The perceived extent of integration of ICT in intra-university communication was measured by assessing the perception on ICT availability and use both by students and staff in each university surveyed. The findings were as indicated below.

\subsection{Students' Perception on ICT Resource Availability for Intra-University Communication}

Students were asked whether they were aware of the availability of ICT resources for intra-university communication in their universities. Their responses were as indicated on Table 1:

Table 1. Awareness of ICT Resources available for Intra-University Communication.

\begin{tabular}{llll}
\hline & & $\begin{array}{l}\text { Whether } \\
(\%)\end{array}$ & Aware of Availability \\
\hline ICT Resources & $\mathbf{N}$ & Yes & No \\
Mobile phone & 231 & 98.7 & 1.3 \\
E-mail & 231 & 92.6 & 7.4 \\
Bulk SMS & 231 & 68.0 & 32.0 \\
\hline & & Source: Field data
\end{tabular}

Table 1 shows that most students were aware of the mo- 
bile phone's use (98.7\%) for intra-university communication. This is probably because use of the mobile phone enables faster communication and feedback. This observation is supported by [10] who argues that mobility, immediacy and instrumentality were the strongest instrumental motives for cell phone use. The mobile phone is also the fastest growing and most popular ICT resource in Kenya. This is due to heavy investment in telecommunications and particularly in mobile phone services [11]. In a study to investigate mobile practices of Irish teenagers, [12] reported that the mobile phone was a deeply embedded device in the lives of teenagers. Table 1 also shows that $92.6 \%$ of students were aware of the availability of e-mail services for intra-university communication. This is an indication that the use of e-mail for intra-university communication has grown tremendously over the years because [13] had earlier reported that $72 \%$ of students in Kenya were using e-mail.

Bulk SMS messaging is the medium that enables instantaneous notification of a target group of people, regardless of their location, on an issue of common interest. From Table 4, $68 \%$ of the students were aware of the existence of the bulk SMS messaging services in their institutions. The reason why the percentage in awareness of bulk SMS system was lower than that of the e-mail was probably because the e-mail has been in use much longer than messaging [14]. When sending the bulk SMS, there is the assurance that it reaches the inbox of the correct recipient and in most cases, it will be the intended recipient who will open it [15]. For this reason most of the universities prefer the SMS rather than e-mail or paper-based communication to reach their customers (students). This explains the high percentage of students who were aware of the existence of bulk SMS messaging in their universities. It has been pointed out by [16] that one in three teens among future students is likely to send more than 100 text messages a day or 3,000 texts within a month. Additionally, [17] noted that 9 in 10 smart phone owners used text messaging with about $95 \%$ of 18 to 29 year olds sending or receiving text messages. Considering these trends, it seems only natural for the university administration to take advantage of this technology already in the hands of students and use it for intra-university communication.

A total of 231 student questionnaires were collected for analysis. An ICT availability index in intra-university communication was computed yielding a mean index of 0.86 \pm 0.21 . The questionnaire items were dichotomously scored by assigning value 0 for a No response and value 1 for Yes response. The scores for each individual respondent were summed up and divided by 3 to get individual mean. Three (3) was the total number of components under ICT availability for intra-university communication. To get the mean score for 231 respondents, the sum of individual index for availability was divided by 231 . The range of scores was 0 to 1. Therefore, a mean score of 0.86 indicated that students were relatively well aware of ICT resources for intra-university communication. The following section contains a report of students' perception of ICT use in in- tra-university communication.

\subsection{Use of ICT Resources by Students for Intra-university Communication}

The students were asked whether they used ICT resources for intra-university communication in their universities. Their responses were as shown on Table 2:

Table 2. Use of ICT by Students for Intra-university Communication

\begin{tabular}{lllll}
\hline \multicolumn{5}{c}{$\begin{array}{l}\text { Whether they use ICT for intra-university commu- } \\
\text { nication (\%) }\end{array}$} \\
\hline ICT Resources & N & Agree & Neutral & Disagree \\
Mobile phone & 230 & 85.7 & 6.1 & 8.2 \\
Email & 185 & 70.4 & 18.7 & 10.9 \\
Bulk SMS & 150 & 64.9 & 0.1 & 35.0 \\
\hline
\end{tabular}

Source: Field data

Table 2 shows that $85.7 \%$ of the students indicated that they used mobile phones for intra-university communication while $70.4 \%$ used e-mail. The reason for the high percentage of mobile phone use could probably be its attributes such as affordability, portability, convenience, cost of calling, versatility, and simplicity in usage. It is pointed out in [3] that the interplay between access, affordability, the growing multi-functionality of mobile devices, and the development and roll-out of mobile applications relevant to the needs of majority of the people, makes the mobile phone popular. In [4] it is argued that mobile phones make communication more efficient, often more private, and increase efficiency in daily activities, time management and general organization. According to [5] which reports on smart-phone functionalities used by different age groups within a 30-day period in November $2010,75 \%$ of $18-24$ year olds surfed the internet on their mobile phones while $69 \%$ of the same age group used the mobile phone to send or receive SMS . This age group is similar to the age of students in the Kenyan universities. Therefore, a general characteristic that affects this group of students is that nearly all of them have mobile phones. They can call the lecturers and the university can communicate with them through the bulk SMS. With Internet enabled mobile phones, they can communicate through e-mail or access their universities' websites for information on various issues of concern.

From Table 2, 70.4\% of students using e-mail for intra-university communication indicated that communication through e-mail had been recognized as a tool for collaboration amongst the students and their lecturers. In a study to explore internet use by students of the university of Dar es Salam, [18] reported that $68 \%$ of students used the email for communication purposes. In a study to investigate the differences between instant messaging and e-mail among college students in USA, [19] pointed out that about $91 \%$ of those aged 18-19 used email. Hence it appears that widespread usage of the mobile phone by this age group is universal among college students.

Table 2 further shows that $64.9 \%$ of the students indicated 
that their universities used the bulk SMS system for intra-university communication. Notable studies on SMS usage have been done in the past and among them are studies by [6]. In a study to explore the reaction of university students towards political SMS campaigns, the researchers found out that students and the young generation in general were difficult to reach with traditional communication tools. Politicians were using mobile technologies such as bulk SMS system to coordinate events and mobilize the students for political campaigns. Another example of bulk SMS use with younger generation was in a US presidential campaign of 2007 where the two major democratic candidates namely Barrack Obama (the current US president) and Hillary Clinton (the immediate past US Secretary of State) used bulk SMS to communicate with the younger voters [20].

The universities' administrators use bulk SMS to coordinate events where the students are away from the university. Bulk SMS enable university administrators to communicate important announcements and notices to all or particular students on issues affecting them [7]. This reduces administrative costs in the long-run due to the SMS effect of reaching many students simultaneously [21]; [7].

An ICT usage index for intra-university communication was computed by assigning value 1 for disagree response, 2 for neutral response and value 3 for agree response. The scores for each individual respondent were summed up and divided by 3 to get individual mean. Three (3) were the total number of items under ICT use for intra-university communication. To get the mean score for 231 respondents, the sum of individual indices for use was divided by 231 . The range of scores was 1 to 3 . A score of $2.11 \pm 0.78$ was obtained for the surveyed student which indicates that students were using ICT resources for intra-university communication.

To determine the extent of ICT integration in intra-university communication from the perception of students, the ICT integration index was computed by summing up the availability index and use index in intra-university communication. The range of scores for ICT integration in intra-university communication was $1-4$. An ICT integration index of $2.96 \pm 0.82$ was obtained.

The lecturers' perception with regard to ICT resource availability and to ICT resource use in intra-university communication is presented Table 3 .

Table 3. Availability of Intra-university Communication resources based on perception of the lecturers

\begin{tabular}{llll}
\hline \multicolumn{4}{l}{ Whether Aware of Availability (\%) } \\
\hline ICT Resources & $\mathbf{N}$ & Yes & No \\
Bulk SMS system & 177 & 79.7 & 20.3 \\
E-mail broadcasts & 177 & 88.4 & 11.6 \\
Mobile phone & 179 & 87.0 & 13.0 \\
\hline
\end{tabular}

Source: Field Data

From Table 3, it is clear that most lecturers were aware of the availability of ICT resources for intra-university com- munication. This is judging by the fact that $88.4 \%$ of the respondents were aware of the e-mail broadcasts while $87 \%$ were aware of the availability of the mobile phone for intra-university communication. On the open-ended part of this question, the lecturers indicated that they were aware of their university's website which was also used for communication. They reported that they were informed of the university reporting dates and graduation dates from their universities' websites. In a study to investigate the use of ICTs in Higher Education Institutions in Mozambique, [22] reported the use of the websites for information communication and service delivery. He pointed out that websites acted as ambassadors that made higher education institutions visible, better linked and satisfy both the digital environment of staff and students.

Ranking of universities and research institutions using their websites has become a common practice. Webometrics ranking is one of the better known ranking of world universities based on their online visibility through their websites [23]. If the content on the website is enriched and the design improved, then the website is likely to be ranked higher in the webometrics ranking. Some of the universities in the study have performed well in the webometrics ranking. As an example in January 2012, University of Nairobi was ranked 17 th in Africa and $1^{\text {st }}$ in Kenya [23]. This meant that the university's website was made available to students, lecturers and the world at large and its content was enriched for good communication with students, lecturers and the external environment.

An ICT availability index for intra-university communication was computed from the lecturers questionnaires. A total of 183 lecturers had responded to this item. A mean index for 183 items was $0.81 \pm 0.28$. The questionnaire was dichotomously scored. The ICT availability index was computed by first assigning value 0 for a No response and value 1 for Yes response. The scores for each individual respondent were summed up and divided by 3 to get individual mean. Three (3) were the total number of items under ICT availability for intra-university communication. To get the mean score for 183 respondents, the sum of individual index for availability was divided by 183 . The range of scores was 0 to 1 . Therefore, a mean score of 0.81 indicated that lecturers were aware of ICT resources for intra-university communication.

\subsection{Lecturers' Perceptions on Use of ICT in In- tra-university Communication}

The lecturers were asked whether they used the ICT resources for intra-university communication. Table 4 shows their responses

It was evident from Table 4 that most lecturers were using ICT resources for intra-university communication. Quick and reliable method of mass communication was important in order to keep the university community informed of important university activities. E-mail broadcasts are communication systems put in place that allows a member of the organization to e-mail all of the organization's active 
members using a single e-mail message. Eighty five point nine percent $(85.9 \%)$ of the lecturers were using the e-mail broadcasts for intra-university communication while $85.5 \%$ used the mobile phone. Email broadcasts would be used as a communication medium if there was no perceived physical presence to accomplish a particular task). For example, email could be used to make announcements such as meeting schedules [19].

Table 4. Use of ICT Resources for Intra-university Communication

\begin{tabular}{|c|c|c|c|c|}
\hline \multirow[b]{2}{*}{ ICT resources } & \multicolumn{4}{|c|}{$\begin{array}{l}\text { Whether they use ICT for intra-university commu- } \\
\text { nication (\%) }\end{array}$} \\
\hline & $\mathbf{N}$ & Agree & Neutral & Disagree \\
\hline $\begin{array}{l}\text { Bulk SMS } \\
\text { system }\end{array}$ & 184 & 72.8 & 8.7 & 18.5 \\
\hline $\begin{array}{l}\text { E-mail } \\
\text { broadcasts }\end{array}$ & 181 & 85.9 & 0 & 14.1 \\
\hline Mobile phone & 185 & 85.5 & 0 & 14.5 \\
\hline
\end{tabular}

Bulk SMS systems on the other hand are designed for simultaneous delivery of messages to multiple users in a specified area. From Table 4, $72.8 \%$ of the lecturers were using the bulk SMS system for intra-university communication. According to [24], SMS was actively used because it offered a cost effective, efficient and convenient way of communicating. When used correctly, SMS technology can offer immediate response, more engagement and interaction [25]. This makes it possible for administrators to communicate with lecturers and students. One characteristic that a mobile phone has is to dislocate the idea of home [26]. This observation is echoed by [9] who argued that mobile ICT are place-independent and time-independent applications. They also pointed out that the application of the mobile phone as a communication medium tends not to occur among social groups who are sharing the same spaces but among dispersed social contacts. This makes it possible for university administrators, students and lecturers to effectively communicate.

An ICT use index in intra-university communication was computed and a mean index for 187 items was $2.65 \pm 0.57$. The ICT use index was computed by first assigning value 1 for disagree response, 2 for neutral and value 3 for agree response. The scores for each individual respondent were summed up and divided by 3 to get individual mean. Three (3) were the total number of items under ICT use for intra-university communication. To get the mean score for 187 respondents, the sum of individual index for use was divided by 187 . The range of scores was 1 to 3 . Therefore, a mean score of 2.65 indicated that lecturers were using ICT resources for intra-university communication.

To determine the extent of ICT integration in intra-university communication from the perception of the lecturers, the ICT integration index was computed by sum- ming up the availability index and use index. The range of scores for ICT integration in intra-university communication was 1-4. An ICT integration index of $3.41 \pm 0.86$ was obtained.

\section{Conclusion}

This research set out to establish availability and level of use of ICT in intra-university communications among Nairobi metropolitan universities in Kenya. The data obtained indicates that the majority of students and staff were aware of the ICT resources available for communication within their institutions and, additionally, used these resources. Considering the high rate of adoption of mobile phones in Kenya, this is not surprising. However, in view of the central role that ICT is expected to play in the economic and social progress of many developing nations more work is needed to establish the extent to which ICT supports educational objectives.

\section{References}

[1] Rettig, J. (2003). Technology, cluelessness, anthropology, and the memex: the future of academic reference service, Reference Services Review, 31 (1), 17-21.

[2] Ruppel, M, and Vecchione, A. (2012). "It's research made easier!" SMS and chat reference perceptions, Reference Services Review, 40 (3) 423 - 448.

[3] McNamara, K. S. (2009). The Significance of Mobile Applications for Developing-Country Agriculture. Draft October 16, 2009.

[4] Hellström, J. (2010). The Innovative Use of Mobile Applications in East Africa, Swedish International Development Cooperation Agency ISBN: 978-91-586-4129-7. Retrieved June, 10, 2012, from http://sidapublications.citat.se/interface/stream/mabstream.a sp?filetype $=1 \&$ orderlistmainid $=2861 \&$ printfileid $=2861 \&$ fil $\mathrm{ex}=3830197052040$.

[5] Mintel. (2011). Mobile phones - US - February 2011: Reports, Mintel Oxygen database.

[6] Priporas C., V. and Mylona, I. (2008). University students attitudes toward mobile political communication. International Journal of Mobile Marketing, 3 (2), 54- 60.

[7] Pal, S. (2010), A model for integrating mobile technology in education management. CURIE Journal, the property of BITS (Birla Institute of Technology \& Science) 3, (3) 28-35.

[8] Mugenda, M. O., and Mugenda, G. A. (1999). Research methods: Quantitative and qualitative approaches. Nairobi: ACTS press.

[9] Kathuri, N. J., and Pals, D. A., (1993). Introduction to Educational Research. Egerton University: Education Media Centre.

[10] Leung, L. and Wei, R. (2000). More than just talk on the move: uses and gratifications of the cellular phone, Journalism and Mass Communication Quarterly, 77, (2), 308-320. 
[11] Tilvawala, K., Myers, M. D., and Andrade, A.D. (2009). Information Literacy in Kenya. EJISDC (2009), 39(1), 1-11.

[12] Cawley, A. and Hynes, D. (2010). Evolving mobile communication practices of Irish teenagers, Aslib Proceedings, 62 (1) $29-45$.

[13] Kashorda, M., \& Waema, T. (2008). E-readiness survey of East African Universities. Retrieved April 7, 2011, from http://kenet.or.ke/eready/staging/E- readiness $\% 20$ Survey $\% 20$ of $\% 20$ East $\% 20$ African $\% 20$ Universities $\% 20$ Report $\% 202009$.pdf

[14] Isaacs, E., Kamm, C., Schiano, D.J., Walendowski, A. \& Whittak, S. (2002). Short talks: characterizing instant messaging from recorded logs, paper presented at Conference on Human Factors in Computer Systems.

[15] Raju, S. (2011). Bulk SMS Services; Published in Cell Phone SMS. Retrieved September 9, 2012, from -http://www.sooperarticles.com/communications-articles/mo bile-sms-articles/bulk-sms-services-274689.html

[16] Lenhart, A., Ling, R., Campbell, S. \& Purcell, K. (2010). Teens, cell phones and texting, Pew Research Centre. Retrieved October 2, 2011, from http://bcsdcybercrimes.com/Documents/Teens, $\% 20$ Cell\%20 Phones\%20and\%20Texting.pdf

[17] Smith, A. (2011). Americans and text messaging, Pew Research Center. Retrieved January 12, 2012, from http:// pewinternet.org/Reports/2011/Cell-Phone-Texting-2011.aspx

[18] Luambano I., \& Nawe, J. (2004). Internet Use by Students of the University of Dar es Salaam, Library Hi Tech News, 21 (10), $13-17$

[19] Lancaster, S., David, C., Y., Albert H., H., \& Shin-Yuan, H.
(2007). The selection of instant messaging or e-mail: College students' perspective for computer communication, Information Management \& Computer Security, 15 (1), 5- 22.

[20] Busk, D. (2007). Election 2008: The mobile tipping point, International Journal of MobileMarketing, 2 (2), 5-9.

[21] Priporas C., V. \& Mylona, I. (2008). Mobile services: Potentiality of SMS as new business communication tool in attracting consumers, International Journal of Mobile Communications, 6(4), 456-466.

[22] Zeininger, M., C. (2009). The Use of Information and Communication Technologies (ICTs) in Higher Education Institutions in Mozambique: Institutional Websites as Ambassadors for Educational Technologies? Made available in the Creative Commons spirit.

[23] University of Nairobi. (2011). Annual Report. Retrieved October 9, 2012, from http://www.uonbi.ac.ke/sites/default/files/UON\%20AR\%20 2010\%20WEB.pdf

[24] Rheingold, H. (2002). "A conversation with Howard Rheingold", in Powazek, D.M. (Ed.), Design for Community: The Art of Connecting Real People in Virtual Places, New Riders, Indianapolis, IN, pp. 286-96.

[25] Mavuso, R., Makana J., P., \& Anbu K., (2012). Old wine in new wine skin: marketing library services through SMS-based alert service, Library Hi Tech, 30 (2) 310 - 320 .

[26] Morley, D. (2006). What's 'home' got to do with it? Contradictory dynamics in the domestication of technology and the dislocation of domesticity, in Berker, T., Hartmann, [19] M., Punie, Y. and Ward, K. (Eds), Domestication of Media and Technology, Open University Press, Maidenhead, pp. 21-49.. 